\title{
Article \\ Genome-Wide Identification and Analysis of the MADS-Box Gene Family in American Beautyberry (Callicarpa americana)
}

\author{
Tareq Alhindi ${ }^{1, *}$ and Ayed M. Al-Abdallat ${ }^{2}$ \\ 1 Department of Biological Sciences, School of Science, The University of Jordan, Amman 11942, Jordan \\ 2 Department of Horticulture and Crop Science, School of Agriculture, The University of Jordan, \\ Amman 11942, Jordan; a.alabdallat@ju.edu.jo \\ * Correspondence: t.alhindi@ju.edu.jo
}

Citation: Alhindi, T.;

Al-Abdallat, A.M. Genome-Wide Identification and Analysis of the MADS-Box Gene Family in American Beautyberry (Callicarpa americana). Plants 2021, 10, 1805. https:// doi.org/10.3390/plants10091805

Academic Editor: Atsushi Fukushima

Received: 19 July 2021

Accepted: 23 August 2021

Published: 30 August 2021

Publisher's Note: MDPI stays neutral with regard to jurisdictional claims in published maps and institutional affiliations.

Copyright: (c) 2021 by the authors. Licensee MDPI, Basel, Switzerland. This article is an open access article distributed under the terms and conditions of the Creative Commons Attribution (CC BY) license (https:/ / creativecommons.org/licenses/by/ $4.0 /)$.

\begin{abstract}
The MADS-box gene family encodes a number of transcription factors that play key roles in various plant growth and development processes from response to environmental cues to cell differentiation and organ identity, especially the floral organogenesis, as in the prominent ABCDE model of flower development. Recently, the genome of American beautyberry (Callicarpa americana) has been sequenced. It is a shrub native to the southern region of United States with edible purplecolored berries; it is a member of the Lamiaceae family, a family of medical and agricultural importance. Seventy-eight MADS-box genes were identified from 17 chromosomes of the C. americana assembled genome. Peptide sequences blast and analysis of phylogenetic relationships with MADS-box genes of Sesame indicum, Solanum lycopersicum, Arabidopsis thaliana, and Amborella trichopoda were performed. Genes were separated into 32 type I and 46 type II MADS-box genes. C. americana MADS-box genes were clustered into four groups: $\mathrm{MIKC}^{\mathrm{C}}, \mathrm{MIKC}^{*}, \mathrm{M} \alpha$-type, and $\mathrm{M} \gamma$-type, while the $\mathrm{M} \beta$-type group was absent. Analysis of the gene structure revealed that from 1 to 15 exons exist in C. americana MADSbox genes. The number of exons in type II MADS-box genes (5-15) greatly exceeded the number in type I genes (1-9). The motif distribution analysis of the two types of MADS-box genes showed that type II MADS-box genes contained more motifs than type I genes. These results suggested that C. americana MADS-box genes type II had more complex structures and might have more diverse functions. The role of MIKC-type MADS-box genes in flower and fruit development was highlighted when the expression profile was analyzed in different organs transcriptomes. This study is the first genome-wide analysis of the C. americana MADS-box gene family, and the results will further support any functional and evolutionary studies of $C$. americana MADS-box genes and serve as a reference for related studies of other plants in the medically important Lamiaceae family.
\end{abstract}

Keywords: bioinformatics; genome-wide assay; MADS-box genes; medicinal plant; plant transcription factors

\section{Introduction}

Mints (Lamiaceae) are the sixth largest family of flowering plants and include many ornamental, medical, and edible species, such as basil, rosemary, thyme, peppermint, and spearmint. Full genome and transcriptome sequencing data that are available at the Mints Genome Project database (http:/ / mints.plantbiology.msu.edu/index.html; accessed on 1 July 2021) and separate other projects are enhancing our understanding of this important medical plant family. American beautyberry (Callicarpa americana) is known for its prominent purple fruit, and it has been reported that native Americans have used it as an insect repellent and medicinal plant [1]. Studies have revealed a number of terpenoids, such as spathulenol, intermedeol, and callicarpenal that have been isolated from the plant, and proved to be effective as a mosquito repellent in laboratory experiments [2,3]. Callicarpa is a representative from the early-diverging mint lineage, and thus, it has an important phylogenetic position to study the evolution of key gene families, such as the MADS-box genes. Recently, the full genome sequence of C. americana has been published [4], providing 
the opportunity to conduct a comprehensive analysis of the C. americana MADS-box gene family. However, the identity and function of MADS-box genes in this species have not been reported in detail.

The MADS-box transcription factor family is of key importance; it can be found in almost all eukaryotes, from protists to animals, but in plants, it is most important for its major role in organ identity and cell differentiation from roots to flower development and fruit ripening and, thus, has been extensively studied [5-7]. Understanding the genes that regulate flower, root, and fruit development is of key importance, on a scientific fundamental level, as well as on an economic level. The MADS-box gene family also has a role in plants' developmental plasticity and responses to abiotic stress such as drought, salinity, extreme temperatures, and nutrient deficiency [8,9]. The acronym MADS represents the first letters of its founding members: mini chromosome maintenance 1 (MCM1) of yeast (Saccharomyces cerevisiae), agamous (AG) of Arabidopsis thaliana, deficiens (DEF) of snapdragon (Antirrhinum majus L.), and serum response factor (SRF) of humans [10]. All MADS-box proteins are characterized by the presence of about 60 amino acids long, DNAbinding domain, known as the MADS-box domain (M-domain), located at the N-terminal region of the proteins. The development of the floral organ is controlled by major groups of MADS-box genes, through the ABCDE model of flower development. In this model, tetramers from different subgroups determine the organ identity; sepal development is directed by the A subfamily genes, petal development requires $\mathrm{A}$ and $\mathrm{B}$ genes, and carpel development is determined by $\mathrm{C}$ genes, whereas stamen development is determined by $\mathrm{B}$ and $C$ genes. While the D-functional genes are needed in ovule development [11-14], and the E-functional genes-acting as the glue that binds different members in the tetramer quartet-are required for the development of all floral organs [15,16].

According to majority of studies, M-type (type I) and MIKC-type (type II) are the two evolutionary lineages of MADS-box genes [17,18]. Both types contain the DNA-binding M-domain. The MIKC-type contains several other conserved domains in addition to the M-domain: an intervening (I) domain, a keratin-like (K) domain, and a C-terminal (C) domain $[19,20]$. Each of these domains has a role in protein-protein interaction with other MADS-box protein forming dimers and tetramers and with non-MADS proteins [21]; in addition, the C-domain is the most variable, and usually, it contains a transcriptional activation domain [13].

The MIKC type II genes can be further classified as MIKC ${ }^{\mathrm{C}}$ ( $\mathrm{C}$ for "classic") and MIKC". The MIKC ${ }^{C}$ type is more diverse, containing thirteen subgroups based on structural differences: SQUAMOSA [SQUA (A)], DEFICIENS/GLOBOSA [DEF/GLO (B)], AGAMOUS [AG (C/D)], SEPALLATA [SEP (E)], AGAMOUS-like; AGL6, AGL12, AGL15, AGL17 (ANR1), B sister (Bsis), SUPPRESSOR OF OVEREXPRESSION OF CO 1 [TM3/SOC1], STMADS11 (SVP), FLOWERING LOCUS C [FLC], and TOMATO MADS 8 [TM8]. While the $\mathrm{MIKC}^{*}$ is less diverse and has only two subgroups MIKC*-S and MIKC ${ }^{*}$-P. Studies showed that the MIKC* type has more conserved functions compared to the M-type and MIKC-type through plants evolution $[15,18,22]$. MIKC ${ }^{*}$-type genes play an essential role in the development of the male gametophyte in A. thaliana, and they have high degree of functional redundancy. The M-type group usually does not contain the K-domain and overall lacks the domains complexity found in MIKC-type proteins. The M-type (type I) genes are divided into three subgroups: $\mathrm{M} \alpha, \mathrm{M} \beta$, and $\mathrm{M} \gamma$ subgroups in most plants [23].

In this study, the MADS-box gene family for $C$. americana (American beautyberry) has been systematically analyzed. A total of 78 MADS-box genes were identified in 17 chromosomes. These genes were renamed CamMADS1 to CamMADS78 based on their locations on the chromosomes, and a phylogenetic tree of all CamMADS genes have been constructed. In addition to C. americana, the type I and type II MADS-box genes of Arabidopsis thaliana, Sesamum indicum, Solanum lycopersicum, and Amborella trichopoda were analyzed and utilized to construct two phylogenetic trees, one for type I and one for type II of these genes. The gene structure and conservative domain in these genes were identified, then the expression patterns of $C$. americana MADS-box genes in various 
tissues were analyzed. In addition, cis-regulatory elements were analyzed and identified in the $2 \mathrm{~kb}$ upstream promoter regions. Results indicated their broad range of functions in several $C$. americana tissues, with major roles in flower and fruit development and abiotic stress response. This study will help in improving our understanding of the evolution and function of this essential transcription factor family, in the medically important Lamiaceae family [24].

\section{Results}

\subsection{Identification of MADS-Box Genes and Their Distribution in C. americana Genome}

Seventy-eight non-redundant MADS-box genes were obtained using the HMMER toolkit [25] to search the hidden Markov model of the MADS-box DNA-binding domain in C. americana proteome sequence, using both SRF (type I) and MEF2 (type II) MADS-box domain sequences (Table 1). Putative MADS-box genes were submitted to the SMART [26] and PROSITE [27] websites for further verification of the presence of the MADS domain. The following C. americana MADS-box genes (CamMADS 9, 11, 27, 35, 38, 47, 60, 61, 68, 77) were identified as type II (MIKC) but they lacked the K-domain. Thus, a further inspection of the genomic data was necessary, and functional sites identification and genome annotation have been carried out using the FGENESH suite [28], using the CamMADS genomic DNA in reference to the $S$. indicum genes. The correct exons have been predicted, and the new CamMADS annotations contained both the M- and K-domains, as expected.

Table 1. Detailed information for the MADS-box gene family in C. americana.

\begin{tabular}{|c|c|c|c|c|c|c|c|c|c|c|}
\hline Gene Name & Gene ID & Chr & Exons & Length (aa) & PI & MW (Da) & Group & Ortholog & E-Value & Subgroup \\
\hline CamMADS1 & Calam.01G080200.1 & 01 & 1 & 119 & 8.58 & $14,045.36$ & M-type & - & - & $\gamma$ \\
\hline CamMADS2 & Calam.01G122600.1 & 01 & 9 & 421 & 4.96 & $48,179.99$ & M-type & - & - & $\alpha$ \\
\hline CamMADS3 & Calam.01G172300.3* & 01 & 6 & 203 & 10.1 & $23,879.46$ & MIKC $C^{c}$ & - & - & SQUA (A) \\
\hline CamMADS4 & Calam.01G249900.1 & 01 & 7 & 234 & 9.5 & $27,268.13$ & $\mathrm{MIKC}^{\mathrm{c}}$ & $A P 3$ & $10^{-90}$ & DEF/GLO (B) \\
\hline CamMADS5 & Calam.01G262900.1 & 01 & 8 & 227 & 5.92 & $25,470.73$ & $\mathrm{MIKC}^{\mathrm{c}}$ & $S V P$ & $10^{-109}$ & STMADS11 (SVP) \\
\hline CamMADS6 & Calam.02G117500.1 & 02 & 1 & 389 & 7.99 & $44,905.13$ & M-type & - & - & $\gamma$ \\
\hline CamMADS7 & Calam.03G039300.1 & 03 & 8 & 253 & 8.45 & $29,036.21$ & MIKC & $C A L$ & $10^{-107}$ & SQUA (A) \\
\hline CamMADS8 & Calam.03G039400.1 & 03 & 8 & 244 & 9.05 & $28,027.89$ & MIKC ${ }^{c}$ & SEP4 & $10^{-89}$ & SEP (E) \\
\hline CamMADS9 & Calam.03G072400.1* & 03 & 8 & 242 & 8.99 & $27,364.05$ & MIKC ${ }^{\mathrm{C}}$ & SEP3 & $10^{-125}$ & FLC \\
\hline CamMADS10 & Calam.03G072500.1 & 03 & 8 & 242 & 8.99 & $27,574.33$ & MIKC & SEP3 & $10^{-127}$ & SEP (E) \\
\hline CamMADS11 & Calam.03G115700.1 * & 03 & 5 & 161 & 9.3 & $18,451.68$ & $\mathrm{MIKC}^{\mathrm{c}}$ & AGL14 & $10^{-46}$ & TM3/SOC1 \\
\hline CamMADS12 & Calam.03G148300.1 & 03 & 1 & 212 & 6.94 & 23,923 & M-type & - & - & $\alpha$ \\
\hline CamMADS13 & Calam.03G148400.1 & 03 & 1 & 183 & 4.96 & $20,172.29$ & M-type & - & - & $\alpha$ \\
\hline CamMADS14 & Calam.04G062300.1 & 04 & 1 & 314 & 9.53 & $34,355.29$ & M-type & - & - & $\alpha$ \\
\hline CamMADS15 & Calam.04G062400.1 & 04 & 1 & 127 & 10.03 & $14,061.52$ & M-type & - & - & $\alpha$ \\
\hline CamMADS16 & Calam.04G062600.1 * & 04 & 1 & 216 & 9.11 & $24,304.77$ & M-type & - & - & $\alpha$ \\
\hline CamMADS17 & Calam.04G062900.1 & 04 & 1 & 99 & 8.96 & $10,888.37$ & M-type & - & - & $\alpha$ \\
\hline CamMADS18 & Calam.04G063300.1 & 04 & 1 & 346 & 5.17 & $37,570.27$ & M-type & - & - & $\alpha$ \\
\hline CamMADS19 & Calam.04G078200.1 & 04 & 9 & 268 & 9.32 & $30,383.48$ & MIKC & AGL24 & $10^{-48}$ & STMADS11 (SVP) \\
\hline CamMADS20 & Calam.04G086600.1 & 04 & 1 & 338 & 8.83 & $38,982.02$ & M-type & - & - & $\gamma$ \\
\hline CamMADS21 & Calam.04G092200.1 & 04 & 1 & 339 & 8.99 & $39,032.72$ & M-type & - & - & $\gamma$ \\
\hline CamMADS22 & Calam.04G128000.1 & 04 & 1 & 241 & 9.27 & 26,959 & M-type & - & - & $\gamma$ \\
\hline CamMADS23 & Calam.04G142100.1 & 04 & 1 & 295 & 9.57 & $32,333.33$ & M-type & - & - & $\alpha$ \\
\hline CamMADS24 & Calam.04G164100.1 & 04 & 7 & 270 & 5.19 & $30,133.31$ & MIKC & AGL15 & $10^{-39}$ & AGL15 \\
\hline CamMADS25 & Calam.04G164200.1 & 04 & 8 & 232 & 5.01 & $26,355.97$ & MIKC ${ }^{\mathrm{c}}$ & AGL15 & $10^{-29}$ & AGL15 \\
\hline CamMADS26 & Calam.04G164300.1 & 04 & 8 & 332 & 5.37 & $37,578.7$ & $\mathrm{MIKC}^{\mathrm{c}}$ & AGL15 & $10^{-45}$ & AGL15 \\
\hline CamMADS27 & Calam.04G209300.1 * & 04 & 5 & 169 & 9.39 & $19,122.03$ & $\mathrm{MIKC}^{\mathrm{c}}$ & SOC1 & $10^{-59}$ & TM3/SOC1 \\
\hline CamMADS28 & Calam.04G209500.1 & 04 & 8 & 251 & 8.91 & $28,497.25$ & $\mathrm{MIKC}^{\mathrm{c}}$ & AGL6 & $10^{-103}$ & AGL6 \\
\hline CamMADS29 & Calam.04G216300.1 & 04 & 1 & 262 & 7.04 & $30,161.8$ & M-type & - & - & $\gamma$ \\
\hline CamMADS30 & Calam.04G237100.1 & 04 & 1 & 261 & 5.74 & $28,960.63$ & M-type & - & - & $\gamma$ \\
\hline CamMADS31 & Calam.05G032500.1 & 05 & 1 & 215 & 8.88 & $24,307.89$ & M-type & - & - & $\alpha$ \\
\hline CamMADS32 & Calam.05G032800.1 & 05 & 1 & 248 & 5.35 & $28,277.95$ & M-type & - & - & $\alpha$ \\
\hline CamMADS33 & Calam.05G039300.2 & 05 & 7 & 277 & 9.26 & $31,920.44$ & MIKC ${ }^{\mathrm{c}}$ & $A G$ & $10^{-117}$ & $A G(C / D)$ \\
\hline CamMADS34 & Calam.05G230800.1 & 05 & 7 & 238 & 9.69 & $27,566.42$ & MIKC & SHP1 & $10^{-111}$ & $\mathrm{AG}(\mathrm{C} / \mathrm{D})$ \\
\hline CamMADS35 & Calam.05G230900.2* & 05 & 9 & 282 & 9.41 & $33,043.92$ & $\mathrm{MIKC}^{\mathrm{c}}$ & SHP1 & $10^{-89}$ & $A G(C / D)$ \\
\hline CamMADS36 & Calam.06G036400.1 & 06 & 1 & 206 & 7.05 & $23,534.14$ & M-type & - & - & $\alpha$ \\
\hline CamMADS37 & Calam.06G036500.1 & 06 & 1 & 249 & 5.18 & $27,366.98$ & M-type & - & - & $\alpha$ \\
\hline CamMADS38 & Calam.06G039300.2* & 06 & 9 & 247 & 9.44 & $28,010.07$ & MIKC ${ }^{\mathrm{c}}$ & $A N R$ & $10^{-80}$ & AGL17 (ANR1) \\
\hline CamMADS39 & Calam.06G055800.1 & 06 & 1 & 296 & 7.78 & $34,434.83$ & M-type & - & - & $\gamma$ \\
\hline CamMADS40 & Calam.06G056500.1 & 06 & 1 & 294 & 7.72 & $33,540.55$ & M-type & - & - & $\gamma$ \\
\hline CamMADS41 & Calam.06G225200.2 & 06 & 8 & 272 & 9.01 & $30,558.2$ & MIKC & AGL15 & $10^{-58}$ & AGL15 \\
\hline CamMADS42 & Calam.06G255900.1 & 06 & 8 & 249 & 8.6 & $28,570.49$ & $\mathrm{MIKC}^{\mathrm{c}}$ & AGL6 & $10^{-101}$ & AGL6 \\
\hline CamMADS43 & Calam.07G213100.1 & 07 & 8 & 247 & 8.25 & $27,924.98$ & $\mathrm{MIKC}^{\mathrm{c}}$ & AGL18 & $10^{-54}$ & AGL15 \\
\hline CamMADS44 & Calam.08G005200.1 & 08 & 7 & 235 & 9.13 & $27,057.88$ & $\mathrm{MIKC}^{\mathrm{c}}$ & AGL21 & $10^{-106}$ & AGL17 (ANR1) \\
\hline CamMADS45 & Calam.08G031600.1 & 08 & 8 & 228 & 6.56 & $25,831.27$ & MIKC & SVP & $10^{-111}$ & STMADS11 (SVP) \\
\hline CamMADS46 & Calam.08G041400.1 * & 08 & 8 & 388 & 5.08 & $44,294.51$ & M-type & - & - & $\alpha$ \\
\hline CamMADS47 & Calam.08G041600.1 & 08 & 11 & 329 & 5.57 & $36,829.16$ & MIKC ${ }^{*}$ & AGL104 & $10^{-60}$ & $S$ \\
\hline CamMADS48 & Calam.08G166600.1 & 08 & 3 & 223 & 9.53 & $25,926.95$ & M-type & - & - & $\alpha$ \\
\hline CamMADS49 & Calam.09G141700.1 & 09 & 8 & 246 & 8.19 & $28,172.93$ & MIKC $^{c}$ & SEP2 & $10^{-120}$ & SEP (E) \\
\hline CamMADS50 & Calam.09G141800.1 & 09 & 8 & 248 & 9.31 & $28,813.63$ & $\mathrm{MIKC}^{\mathrm{c}}$ & $A P 1$ & $10^{-64}$ & SQUA (A) \\
\hline CamMADS51 & Calam.10G107400.1 & 10 & 7 & 213 & 7.82 & $25,002.75$ & $\mathrm{MIKC}^{\mathrm{c}}$ & PI & $10^{-82}$ & $\mathrm{DEF} / \mathrm{GLO}(\mathrm{B})$ \\
\hline
\end{tabular}


Table 1. Cont

\begin{tabular}{|c|c|c|c|c|c|c|c|c|c|c|}
\hline Gene Name & Gene ID & Chr & Exons & Length (aa) & PI & MW (Da) & Group & Ortholog & E-Value & Subgroup \\
\hline CamMADS52 & Calam.10G116200.1 & 10 & 3 & 249 & 4.97 & $26,032.55$ & M-type & - & - & $\alpha$ \\
\hline CamMADS53 & Calam.10G116300.1 & 10 & 1 & 406 & 5.46 & $43,692.96$ & M-type & - & - & $\alpha$ \\
\hline CamMADS54 & Calam.10G116700.1 & 10 & 1 & 360 & 5.41 & $39,162.3$ & M-type & - & - & $\alpha$ \\
\hline CamMADS55 & Calam.10G171700.1 & 10 & 7 & 209 & 9.08 & $23,889.61$ & MIKC $^{\mathrm{c}}$ & AGL19 & $10^{-68}$ & TM3/SOC1 \\
\hline CamMADS56 & Calam.11G009500.1 & 11 & 7 & 213 & 8.76 & $24,464.63$ & $\mathrm{MIKC}^{\mathrm{c}}$ & AGL12 & $10^{-65}$ & AGL12 \\
\hline CamMADS57 & Calam.11G010000.1 & 11 & 7 & 221 & 9.55 & $25,595.38$ & MIKC ${ }^{\mathrm{C}}$ & STK & $10^{-100}$ & $\mathrm{AG}(\mathrm{C} / \mathrm{D})$ \\
\hline CamMADS58 & Calam.11G011000.1* & 11 & 1 & 182 & 9.38 & $20,612.54$ & M-type & - & - & $\gamma$ \\
\hline CamMADS59 & Calam.11G041000.1 & 11 & 6 & 251 & 6.84 & $29,406.47$ & MIKC $^{c}$ & $A B S$ & $10^{-51}$ & Bsis \\
\hline CamMADS60 & Calam.11G131900.1 & 11 & 11 & 326 & 5.5 & $37,186.12$ & MIKC* & AGL66 & $10^{-54}$ & $\mathrm{~S}$ \\
\hline CamMADS61 & Calam.12G155600.11 & 12 & 10 & 370 & 5.76 & $46,664.87$ & MIKC $^{*}$ & AGL65 & $10^{-80}$ & $\mathrm{P}$ \\
\hline CamMADS62 & Calam.12G166700.1 & 12 & 8 & 236 & 9.11 & $27,139.8$ & MIKC ${ }^{c}$ & FUL & $10^{-82}$ & SQUA (A) \\
\hline CamMADS63 & Calam.13G078400.1 & 13 & 7 & 244 & 9.17 & $28,250.83$ & $\mathrm{MIKC}^{\mathrm{c}}$ & SHP1 & $10^{-105}$ & $\mathrm{AG}(\mathrm{C} / \mathrm{D})$ \\
\hline CamMADS64 & Calam.13G161700.1* & 13 & 6 & 229 & 9.13 & $26,437.96$ & MIKC ${ }^{\mathrm{C}}$ & $A G$ & $10^{-107}$ & $\mathrm{AG}(\mathrm{C} / \mathrm{D})$ \\
\hline CamMADS65 & Calam.14G029500.1 & 14 & 8 & 245 & 7.65 & $28,377.37$ & $\mathrm{MIKC}^{\mathrm{c}}$ & AP1 & $10^{-117}$ & SQUA (A) \\
\hline CamMADS66 & Calam.14G029600.1 & 14 & 8 & 245 & 9.18 & $27,993.7$ & $\mathrm{MIKC}^{\mathrm{c}}$ & SEP4 & $10^{-82}$ & $\widehat{S E P}(\mathrm{E})$ \\
\hline CamMADS67 & Calam.14G070200.1 & 14 & 7 & 210 & 9.32 & $24,190.64$ & MIKC ${ }^{c}$ & $F Y F$ & $10^{-80}$ & TM3/SOC1 \\
\hline CamMADS68 & Calam.14G138300.1* & 14 & 7 & 198 & 7.63 & $22,305.52$ & $\mathrm{MIKC}^{\mathrm{c}}$ & FLC & $10^{-34}$ & FLC \\
\hline CamMADS69 & Calam.14G138400.2 & 14 & 8 & 241 & 8.81 & $27,314.03$ & MIKC ${ }^{c}$ & SEP3 & $10^{-126}$ & SEP (E) \\
\hline CamMADS70 & Calam.15G063200.4 & 15 & 9 & 300 & 7.65 & $31,373.45$ & $\mathrm{MIKC}^{\mathrm{c}}$ & FUL & $10^{-94}$ & SQUA (A) \\
\hline CamMADS71 & Calam.15G133600.1 & 15 & 1 & 282 & 8.46 & $31,931.5$ & M-type & - & - & $\gamma$ \\
\hline CamMADS72 & Calam.15G133700.1 & 15 & 1 & 260 & 6.37 & $29,363.63$ & M-type & - & - & $\gamma$ \\
\hline CamMADS73 & Calam.15G135000.1 & 15 & 1 & 217 & 9.38 & $24,754.44$ & M-type & - & - & $\gamma$ \\
\hline CamMADS74 & Calam.15G135100.1 & 15 & 1 & 218 & 9.52 & $24,769.46$ & M-type & - & - & $\gamma$ \\
\hline CamMADS75 & Calam.16G114400.2 & 16 & 7 & 195 & 9.56 & $22,684.08$ & MIKC ${ }^{\mathrm{C}}$ & TM8 & $10^{-85}$ & TM8 \\
\hline CamMADS76 & Calam.17G013600.1 & 17 & 7 & 223 & 9.57 & $25,780.54$ & MIKC ${ }^{\mathrm{c}}$ & STK & $10^{-89}$ & $\mathrm{AG}(\mathrm{C} / \mathrm{D})$ \\
\hline CamMADS77 & Calam.17G075300.1* & 17 & 7 & 211 & 9.28 & $24,291.01$ & $\mathrm{MIKC}^{\mathrm{c}}$ & $A G L 71$ & $10^{-59}$ & TM3/SOC1 \\
\hline CamMADS78 & Calam.17G076100.1 & 17 & 7 & 194 & 9.64 & $22,181.55$ & MIKC ${ }^{c}$ & AGL13 & $10^{-48}$ & AGL6 \\
\hline
\end{tabular}

* Gene annotation has been corrected. $\mathrm{Chr}=$ chromosome. TM8 gene is present in S. lycopersicum but not in A. thaliana.

Each MADS-box protein was then verified by BLASTP function at the Plant Transcription Factor Database $[29,30]$ separately against $A$. thaliana, S. lycopersicum and S. indicum and finally against all species. CamMADS proteins were then initially categorized into type I (M-type) and type II (MIKC) based on their homology with their identified orthologues; Table 1 includes $A$. thanliana type II MADS-box genes orthologs, while type I CamMADS have low identity alignment scores to $A$. thaliana to be confidently assigned a specific ortholog. As reported in previous studies of other species, the number of type II MADS-box genes was higher than that of type I MADS-box genes. Five MADS-box proteins were neutral, with $\mathrm{pI}$ values between 6.5 and $7.5,18$ were acidic, with $\mathrm{pI}$ values less than $6.5,55$ were alkaline, with $\mathrm{pI}$ values greater than 7.5. It is worth noting that the average $\mathrm{pI}$ for M-type proteins was 7.5, and for the MIKC ${ }^{C}$ group, it was 8.5 (basic), while all MIKC $C^{*}$ proteins had acidic $\mathrm{pI}$ values, with a 5.6 average. The average predicted molecular weight for M-type proteins was 30,261.9 Da, and for MIKC ${ }^{\mathrm{C}}, 27,866.9 \mathrm{Da}$, while the MIKC* proteins had the highest molecular weight average of $40226.7 \mathrm{Da}$. The number of exons in CamMADS genes ranged from 1 to 15 exons. The number of exons in type II MADS-box genes (7-15) greatly exceeded the number in type I genes (1-7). The number of exons within the same subgroup did not vary much, with few exceptions.

After verification of the presence of the MADS-box domain and initial homology alignments, genes were mapped onto the 17 chromosomes of $C$. americana genome, and no MADS-box genes were located on the unanchored scaffolds (Figure 1). The distribution of C. americana MADS-box genes (CamMADS) was uneven. The maximum number of genes (17; 21.79\%) was localized on Chromosome 4, whereas Chromosomes 2, 7, and 16 have only one MADS-box gene each. Several CamMADS genes resided in a 2-5 genes cluster. To investigate possible gene duplication events, the OrthoFinder algorithm was utilized [31], and each two or more adjacent homologous genes located on a single chromosome were considered as co-linear duplicates. A total of 15 paralogous gene pairs were observed, of which four genes were MIKC-type (CamMADS 9, 10, 34, 35) and eleven were M-type (CamMADS 20, 21, 39, 40, 52, 53, 54, 71, 72, 73, 74). 


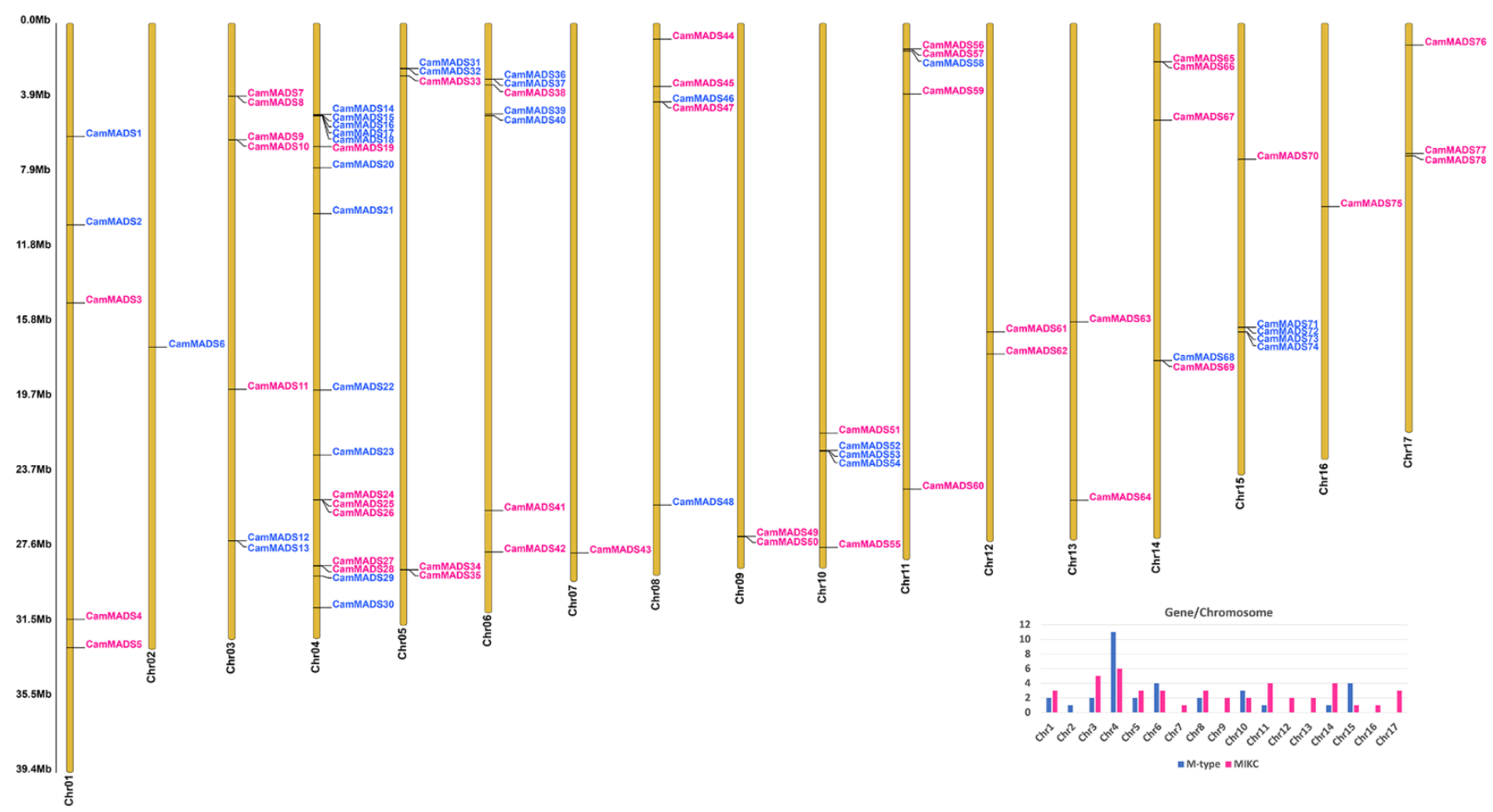

Figure 1. Chromosomal localization of the seventy-eight C. americana MADS-box genes. The number of each chromosome is given under the lines, blue indicates M-type genes, and pink indicates MIKC-type. The right side of each chromosome is related to the approximate physical location of each MADS-box gene. Bottom right: a plot of the number and type of CamMADS genes per chromosome.

\subsection{Phylogenetic Analysis of MADS-Box Genes in C. americana}

To properly classify the CamMADS proteins, three phylogenetic trees (maximum likelihood (ML) tree) for (1) all identified CamMADS proteins (Figure 2), (2) for type I (Figure 3), and (3) for type II (Figure 4) MADS-box proteins were constructed using type I and type II MADS-box full length proteins from A. thaliana, S. lycopersicum (species with well characterized MADS-box genes), S. indicum (a species in lamiaceae family), $A$. trichopoda (a basal outer group), and the CamMADS proteins identified in the present study. CamMADS proteins were classified into functional groups according to both $A$. thaliana and S. lycopersicum MADS-box genes that have been investigated extensively [32,33]. Based on the phylogenetic tree and structural features of the MADS-box proteins, genes were separated into 46 type II and 32 type I MADS-box genes. CamMADS genes were clustered into four groups: type II (MIKC $\left.{ }^{\mathrm{C}}, \mathrm{MIKC}^{*}\right)$ and type I (M $\alpha$-type, $\mathrm{M} \gamma$-type), while the type I $\mathrm{M} \beta$-type group was absent (Figure 3). The $\mathrm{M} \beta$-type group was also absent in S. indicum (sesame) [34]. While type II (Figure 4) phylogenetic tree included all expected groups and subgroups, in accordance with A. thaliana and S. lycopersicum trees. 


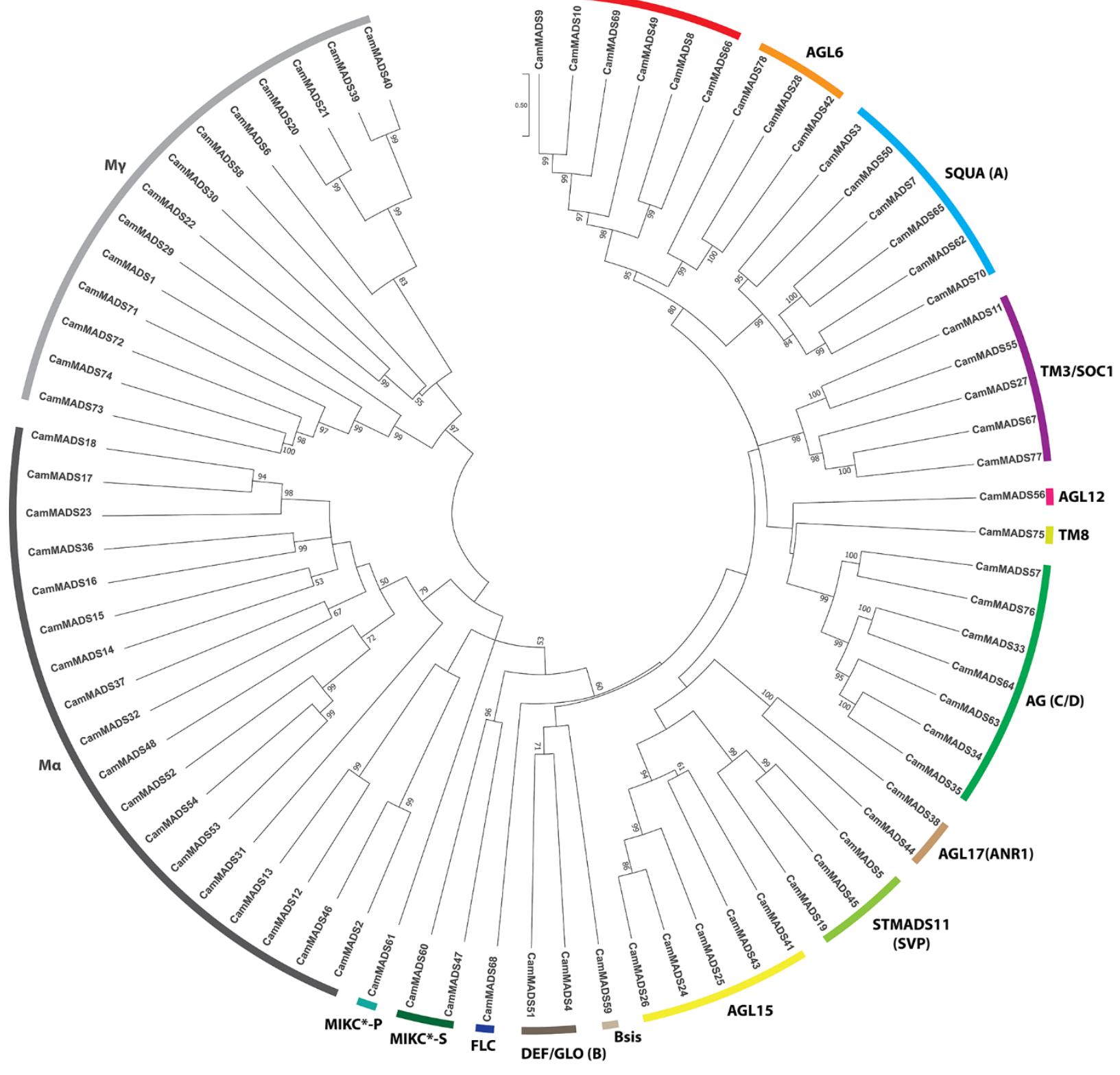

Figure 2. Maximum likelihood tree of CamMADS proteins in C. americana. The tree shows type I subgroups (M $\alpha$-type, M $\gamma$-type), while the type I M $\beta$-type group was absent. Type II subgroups; MIKC ${ }^{C}$ (SQUA (A), DEF/GLO (B), AG (C/D), SEP (E), AGL6, AGL12, AGL15, AGL17 (ANR1), Bsis, TM3/SOC1, STMADS11 (SVP), FLC, and TM8. The MIKC* subgroups (MIKC*-S and MIKC*). 


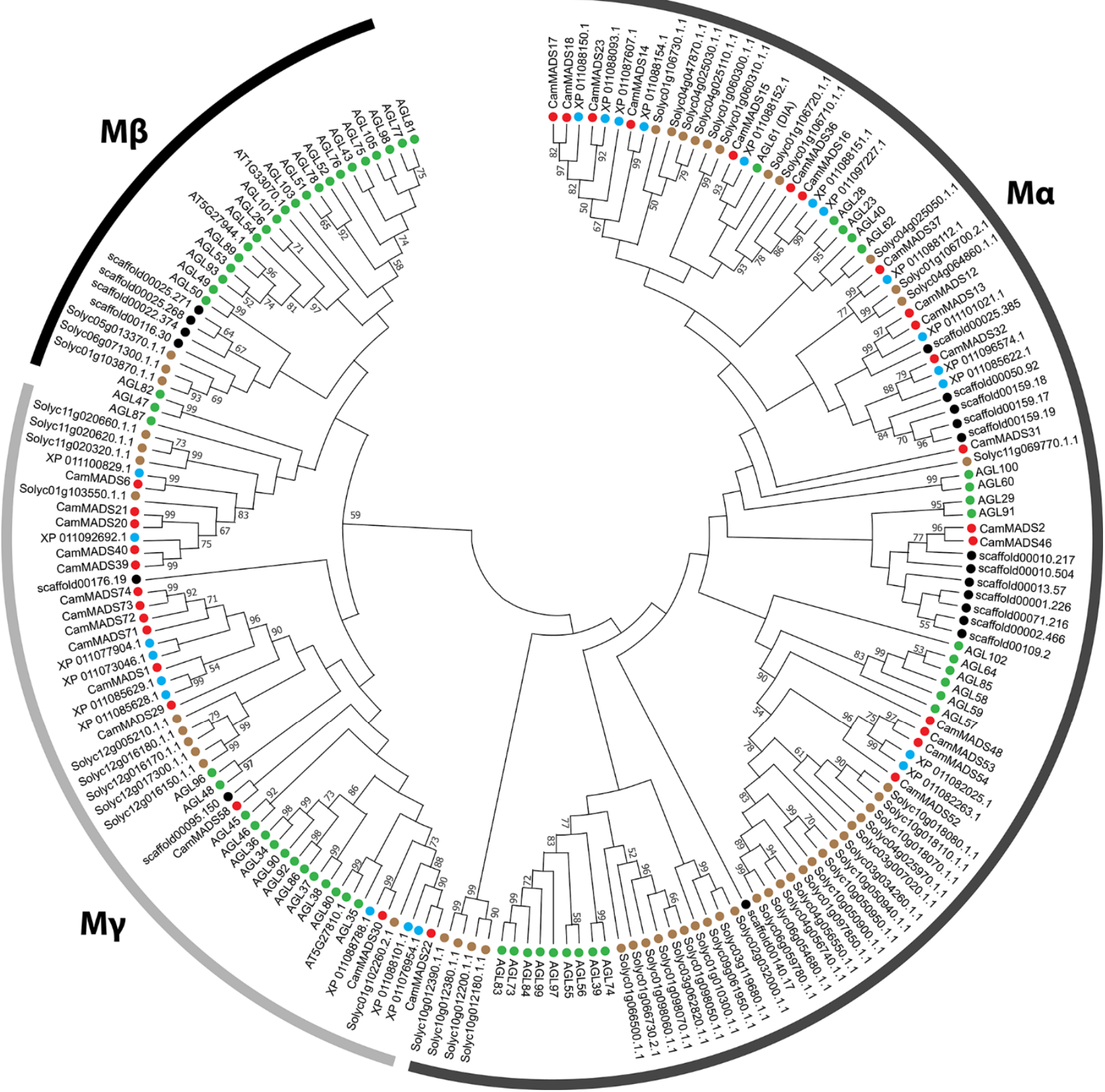

Figure 3. Maximum likelihood tree of type I MADS-box gene proteins in C. americana, A. thaliana, S. lycopersicum, S. indicum, and $A$. trichopoda. The MADS-box proteins contained in the branches for each species are indicated by different colored circles: red, C. americana; green, A. thaliana; brown, S. lycopersicum; blue, S. indicum; black, A. trichopoda. For type I MADS-box proteins ML tree with branch length scale, see Supplementary Figure S1. 


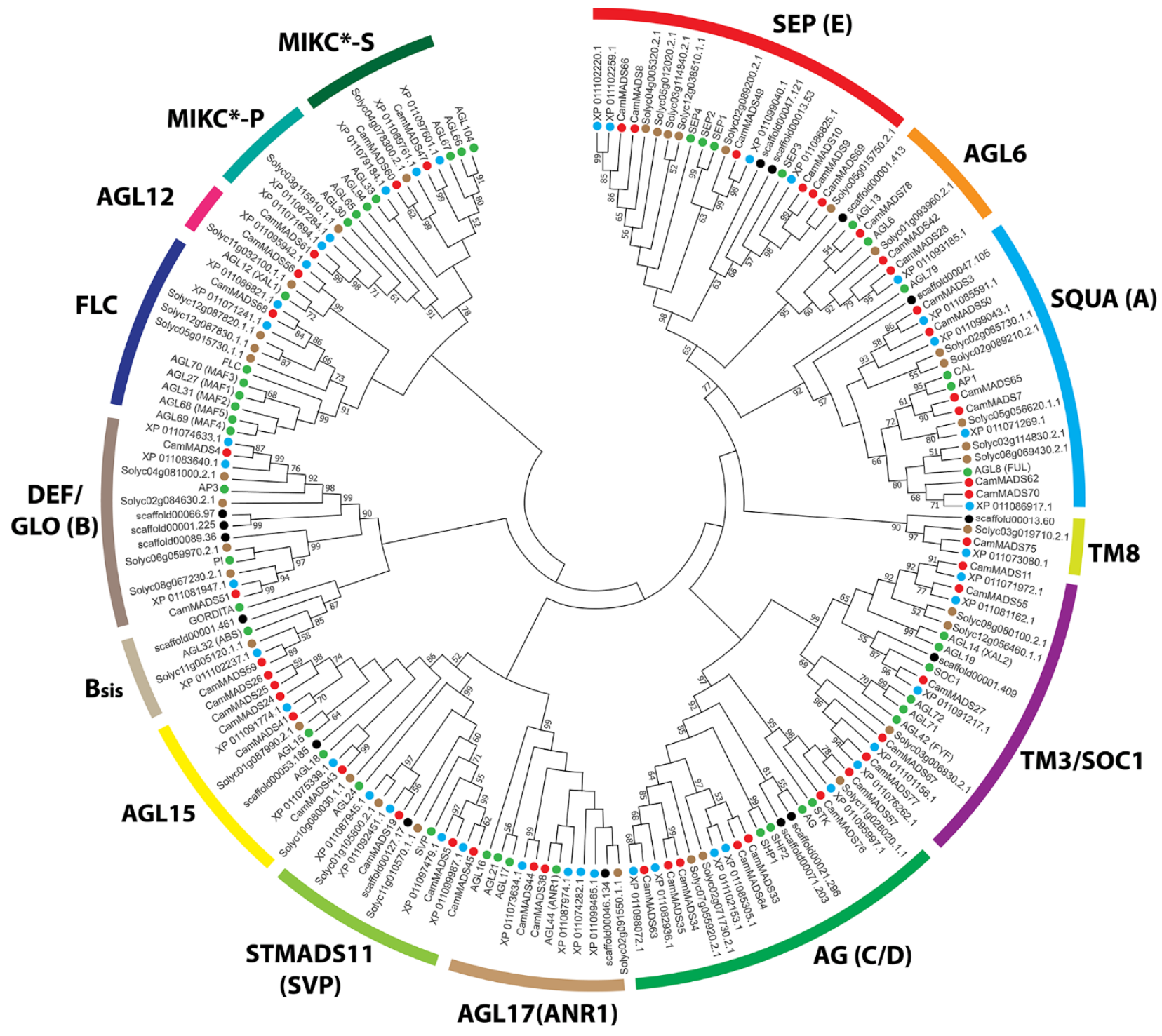

Figure 4. Maximum likelihood tree of type II MADS-box proteins in C. americana, A. thaliana, S. lycopersicum, S. indicum, and A. trichopoda. The MADS-box proteins contained in the branches for each species are indicated by different colored circles: red, C. americana; green, A. thaliana; brown, S. lycopersicum; blue, S. indicum; black, A. trichopoda. For type II MADS-box proteins ML tree with branch length scale, see Supplementary Figure S2.

\subsection{Conservative Motif Distribution and Gene Structure Analysis of C. americana MADS-Box Genes}

To better analyze the sequence characteristics and structural differences among the conserved motifs of all CamMADS proteins (list of CamMADS peptide sequences is available in the Supplementary Data), motifs were predicted by the MEME program (Figure 5B). Motifs 1 and 16 represent the DNA binding MADS domain, and Motif 1 was the most typical MADS domain, 50 amino acids in length. Motifs 2 and 4 combined were the highly conserved K-domain (spanning K1, K2, and K3 subdomains). These motifs were present in all MIKC-type CamMADS genes. It is worth noting that even when the MEME suite did not recognize some K-domains in few CamMADS proteins, a second check by SMART and MotifFinder suites was enough to confirm that the K-domain was present. The length of the conserved K-domain $(\mathrm{K} 1+\mathrm{K} 2+\mathrm{K} 3)$ was $67(38+29)$ amino acids. In general, CamMADS proteins of the same subgroup had similar motifs, and it is probable that they might have conserved functions. While, the difference in motifs structure and distribu- 
tion support the expected variety of function of CamMADS genes in different organs of C. americana.

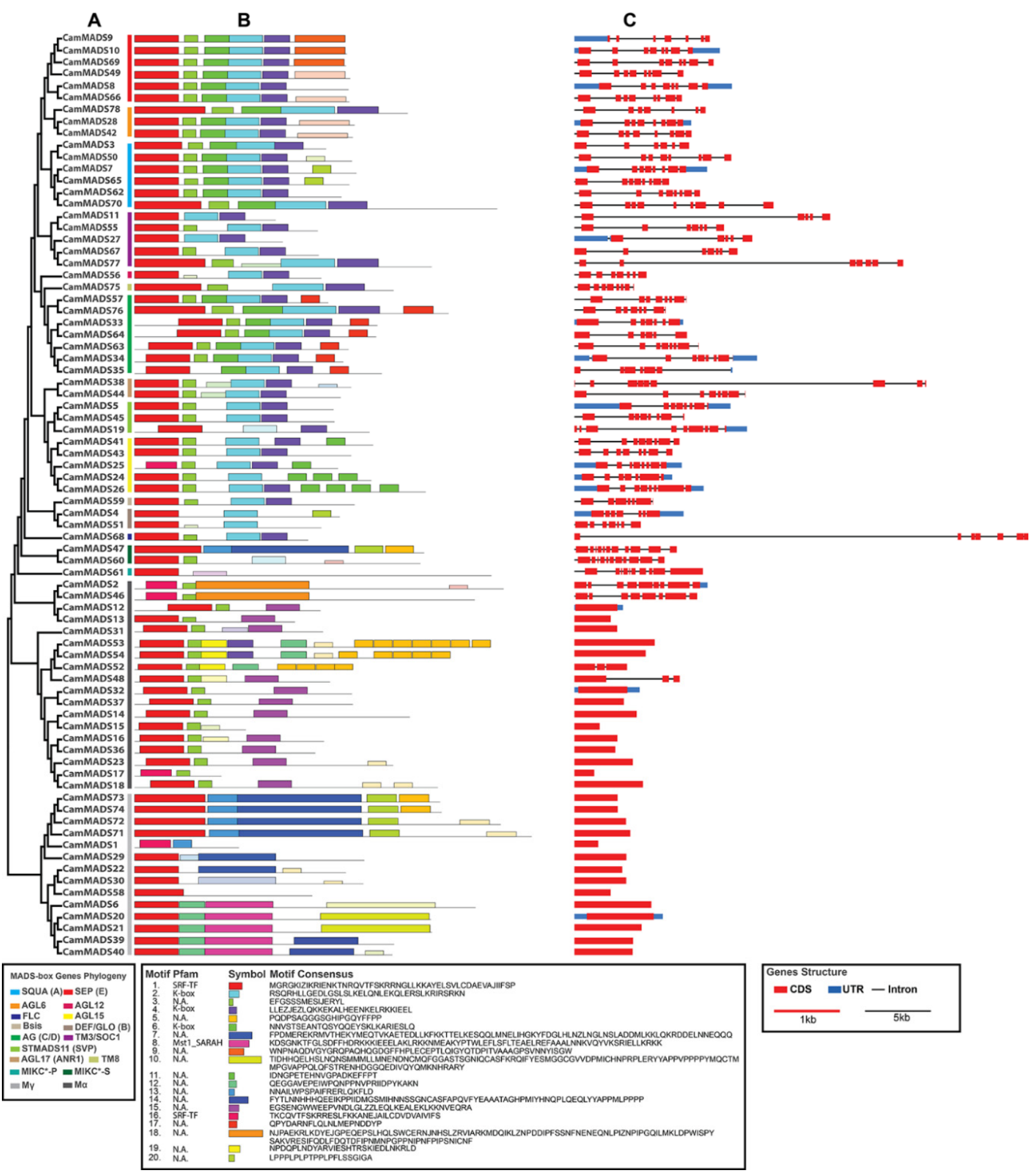

Figure 5. Gene structure and conserved motif analysis of C. americana MADS-box proteins: (A) CamMADS proteins phylogenetic relationship, (B) motif analysis of CamMADS proteins, each motif is represented by a number in a colored box mid-bottom. Box length corresponds to motif length, (C) CamMADS gene structure analysis (exons are in red, introns represented by solid line, and untranslated regions are in blue).

To gain insights into the structural diversity of $C$. americana MADS-box genes, we analyzed the exon-intron organization of the coding sequences of each CamMADS gene (Figure 5C). The number of exons followed a clear bimodal pattern. The type II (MIKC) CamMADS all had at least five introns (CamMADS11 and 27 in TM3/SOC1 group), up 
to 15 exons (CamMADS3 in SQUA group). While all type I (M-type) had only one exonno introns-except, in the M $\alpha$ group where CamMADS48 and 52 had three exons, and CamMADS46 and 2 had 8 and 9 exons, respectively, and in the M $\gamma$ group with CamMADS58 having seven exons. Few genes in the MIKC group have relatively long introns ( $>10 \mathrm{~kb})$, compared to the rest of CamMADS genes.

\subsection{Expression of C. americana MADS-Box Genes}

The expression profile heat map of the 78 CamMADS genes was generated using the transcript per million (TPM) data [2]. CamMADS genes expression was analyzed in the following tissues: mature leaf, young leaf, stem, petiole, root, open flower, closed flower, and whole fruit, as shown in Figure 6. Overall, the CamMADS genes were active in all plant tissues under study, indicating their versatile role in many key physiological activities. The type II (MIKC) CamMADS genes had higher expression in the floral organ and later fruit, some of which were strictly expressed in the floral organ, which is expected as they are key regulators of the florogenesis process. The expression pattern suggests that the ABCDE model of flower development is also conserved in C. americana.

The MIKC subgroup DEF/GLO (B) members CamMADS51 and CamMADS4 genes have the highest expression values in closed and open flower tissues. The SEP (E) subgroup has a high expression level in the open and closed flower as expected, in addition to the whole fruit. While, CamMADS64, a member of the AG (C/D) subgroup, has the highest relative expression value at whole fruit tissue. Most of the type I CamMADS genes have relatively very low to no expression (0 TPM) at most of the tested tissue samples, while few others have moderate expressivity in all tissues. Among the type I MADS-box genes in C. americana, CamMADS6, a member of $\mathrm{M} \gamma$ sub-group, in addition to CamMADS13 and CamMADS31, were expressed in all analyzed tissues. CamMADS58 has a similar expression pattern except in roots. While, CamMADS17 and CamMADS20 genes were expressed in the flower bud tissues.

To further assess the functions of CamMADS genes, the upstream $2 \mathrm{~kb}$ promoter region was analyzed for cis-acting regulatory elements, as shown in Figure 7. The following elements of key roles have been identified: W-boxes and TC-reach repeats are defense and stress-inducible promoters. AE-box, AT1-motif, chs, Box4, TCT-motif, G-box, and GT1-motif are involved in light responsiveness. MBS is the drought resistance-induced MYB binding site. ABRE is an abscisic acid response element. MeJA is the CGTCA-motif methyl jasmonate response element. AuxRR-core and TGA-element are regulatory auxin responsiveness elements. P-box, GARE-motif, and TATC-box are gibberellin response elements. STRE and WUN-motif are wound response elements. ARE is an anti-oxidant response element. O2-site is involved in zein metabolism regulation. GCN4_motif is involved in endosperm expression. CAT-box is related to meristem expression. TCA-motif is a salicylic acid response element. Circadian are cis-acting regulatory element involved in circadian control. LTR is involved in low-temperature responsiveness. MBSI is involved in flavonoid biosynthetic gene regulation.

All CamMADS genes have at least one regulatory element involved in light responsiveness. All have elements involved in wound response, except CamMADS46. Fifty-three genes have an abscisic acid response element. Forty-one genes have a methyl jasmonate response element. Twenty-six genes have either one or both of auxin responsiveness elements. Thirty-four genes have gibberellin response elements. Thirteen genes have an element involved in circadian control. Twenty-nine genes have elements involved in low-temperature responsiveness. A number of genes have different elements involved in metabolism and cell differentiation.

The upstream promoter regions were scanned for elements of GAGA (C-box), mainly GAGAGA hexamers and TGACGT-containing elements. Considering the other possible variation in the GA rich regions [35,36], all promoters had at least one of the aforementioned elements. In addition, all promoters have TATA-box and CAAT-box elements. 


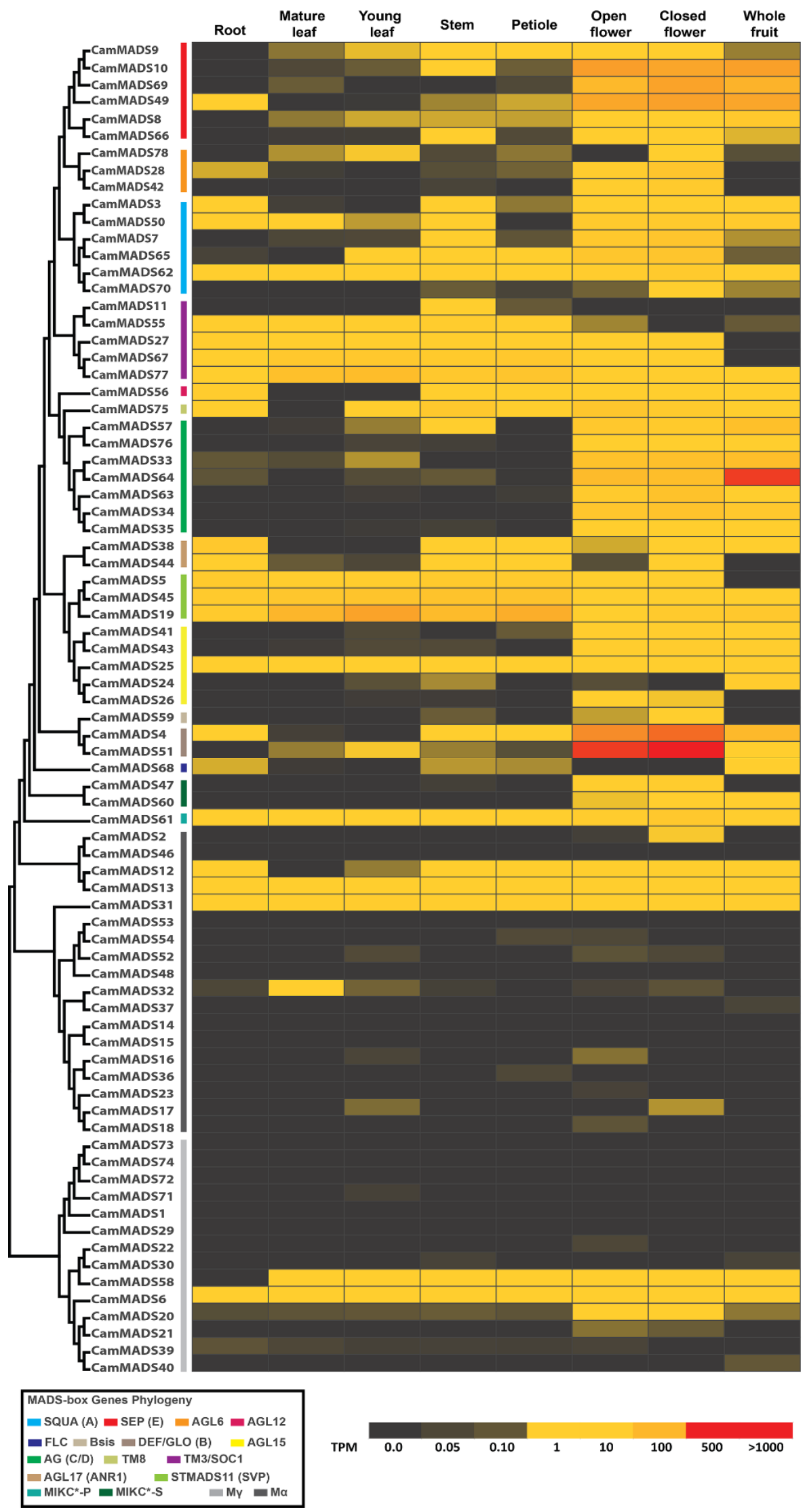

Figure 6. Heatmap of CamMADS genes expression level (TPM) is each of the following tissues: root, mature leaf, young leaf, stem, petiole, open flower, closed flower, and whole fruit. The phylogenetic tree is to the far left, and the box at the bottom left indicates the subgroups of CamMADS genes. 


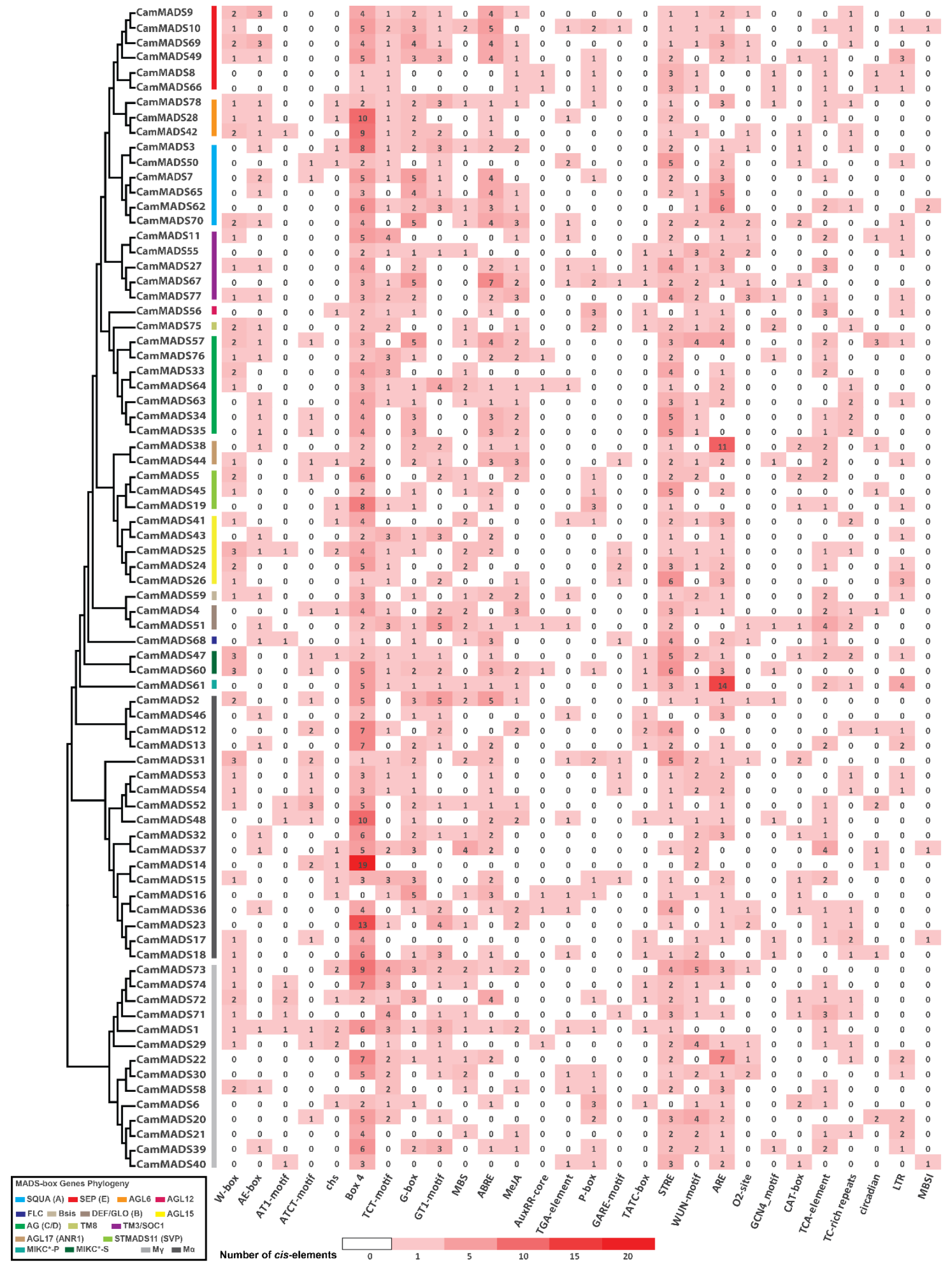

Figure 7. Analysis of Cis-acting elements of MADS-box gene family in C. americana: W-boxes, TC-reach repeats, AE-box, AT1-motif, chs, Box4, TCT-motif, G-box, GT1-motif, MBS, MYB binding site, ABRE, MeJA, AuxRR-core, TGA-element, P-box, GARE-motif, TATC-box, STRE, WUN-motif, ARE, O2-site, GCN4_motif, CAT-box, TCA-motif, Circadian, LTR, and MBSI. 


\section{Discussion}

MADS-box genes have been identified in several species, both the numbers and the types of MADS-box genes differed greatly among these species. Some species had very few type I (M-type) genes or lacked them totally, as in: Saccharum officinarum (grass), Marchantia polymorpha (Marchantiophyta), Klebsormidium flaccidum, Dunaliella salina, and Chlorella variabilis (Algaea). While, the Angiosperms species Amaranthus hypochondriacus and Jatropha curcas have ten genes. Several algae species had very few or lacked the type II (MIKC) genes, as in: Bathycoccus prasinos, Chlamydomonas reinhardtii, and Volvox carteri. Marchantia polymorpha (Marchantiophyta) has two type II (MIKC) genes, and Picea abies (Pinophyta) has three. While, the Angiosperms specie Daucus carota has five genes. Angiosperms also have the largest number of type I genes (Camelina sativa: 271 genes) and the largest number of type II genes (Glycine max, Soybean: 209 genes) [29,30].

The number of type I MADS-box genes in C. americana (32) was similar to S. indicum (31), but lower than Ocimum tenuiflorum (42), all members of Lamiaceae family. While, the number of type II genes in C. americana (46) was higher than that in O. tenuiflorum (43) but lower than $S$. indicum (62). The genome size of C. americana was $506.1 \mathrm{Mb}$ [4], compared to the genome size of S. indicum $337 \mathrm{Mb}$ [34] and $612 \mathrm{Mb}$ estimated genome size for O. tenuiflorum [37]. When compared to the large soybean genome (1115 M) [34,38], which also has 269 MADS box genes, and Camelina sativa estimated the genome size of $785 \mathrm{Mb}$ [39], which has 384 MADS box genes. The reduced number of genes in some Lamiaceae members might be justified by the smaller genome size and/or more active genome size reduction after duplication events, since the whole genome duplication event is a main contributor for the genes' number increment and diversification of species [40-43]. The clustering of genes is observed in other transcription factor families, such as Hox genes [44]. This clusters might have risen through tandem gene duplication events [18,45]. The high exon number in type II (MIKC) genes (5-15) compared to type I (1-9) is consistent with studies in other species, such as sesame, Arabidopsis, rice, and soybeans [32,34,38]. This also matches the more complex and versatile functions found in type II (MIKC) compared to type I (M-type) $[7,12,18,23]$.

The M $\beta$-type of type I MADS-box genes was absent in C. americana; also, it was absent in S. indicum and $U$. gibba [34]. The absence of $\mathrm{M} \beta$-type genes in these species, which are all members of the Lamiales order, is an indication of a close relationship between the Lamiacaea family (C. americana and S. indicum) and Lentibulariaceae family (U. gibba) within the Lamiales order. The function of most $\mathrm{M} \beta$-type genes in Arabidopsis is not fully understood, but some play important roles in the differentiation of female gametophyte [32,46]. Either there is a different mechanism in C. americana due to the lack of $\mathrm{M} \beta$-type genes, or there was a redundancy in their function and other CamMADS protein can still fill their role in the protein network. $\mathrm{M} \beta$ genes were reported to be absent in rice and other monocots as well [32], and the subgroup might have evolved as a lineagespecific clade.

CamMADS75 is an ortholog of TM8 gene present in S. lycopersicum, S. indicum, and A. trichopoda, but absent in A. thaliana. TM8-like genes were identified in gymnosperms and angiosperms. The pattern of genes expression in several different tissues and the lack of a clear associated phenotype related to TM8 deletion or overexpression render it difficult to pinpoint an exact function, and it could indicate that TM8-like genes are a clade of fast evolving genes [31,47]. Its promoter region has elements involved in stress and drought response, jasmonate and gibberellin response elements, and the GCN4_motif, which is involved in endosperm expression. Further molecular and systematic analysis of C. americana CamMADS75 TM8 ortholog could provide useful information on the function of this elusive gene.

In general, in each studied tissue, there was at least one CamMADS active gene being expressed. This hints to the importance and diversity in functions of this gene family in the C. americana plant. Type II CamMADS genes have an overall higher expressivity across all tissues compared to type I CamMADS. This is expected and can be justified, as the MIKC 
type genes are more complex and diverse than the M-type genes [7,12,18,23]. CamMADS51, an ortholog of Arabidopsis PISTILLATA (PI) gene, has the highest expression level in closed flower sample, along with CamMADS4, an ortholog of the Arabidopsis APETALA3 (AP3) gene. This is reasonable for the key roles that PI and AP3 plays during the florogenesis [19]. CamMADS64 an ortholog of Arabidopsis AG gene was highly expressed in whole fruit sample [48-50]. CamMADS68, an ortholog of Arabidopsis FLC, was suppressed during flower development, since it is a suppressor of flowering, implying that it has a conserved function in C. americana $[14,21,23]$. CamMADS47 and CamMADS60, members of the MIKC*$\mathrm{S}$ subgroup, were expressed in flower tissues, hinting to a possible conserved function during male gametophyte development $[15,18,22]$.

Some of the MIKC group genes were expressed in root, stem, and leaves tissues in addition to their key role in florogenesis. This is consistent with the patterns of MADS-box gene expression in $A$. thaliana where several genes are involved in biological processes other than florogenesis. A. thaliana FLM and FLC are involved in vernalization. FLC, SVP, and SOC1 are involved in drought response; the presence of cis-acting regulatory elements in the promoter regions involved in drought response in ortholog CamMADS implies a possible conservation of functions. ANR1 and AGL21 are involved in lateral root formation; both respective ortholog CamMADS38 and CamMADS44 are expressed in the C. americana root. SOC1, AGL21, and FLC are involved in abscisic acid (ABA) and gibberellin (GA) metabolism [8]; their orthologs in C. americana have the cis-acting regulatory elements involved in ABA and gibberellin GA metabolism. These functions might be conserved in C. americana as well, for the orthologs expression profile can justify the presence of these subgroups' members in the plants' respective tissues.

All promoters had at least one of the GAGA (C-box) elements, which is required for the normal expression of a wide range of different genes; it can facilitate activation by a remote enhancer. Cytokinin response elements was shown to interact with the C-box in A. thaliana [51,52]; a similar mechanism could be at play here in C. americana.

In addition to the upstream promoter region, the first intron of each CamMADS genes-when available-was scanned for cis-regulatory elements, all introns contained TATA-box and/or CAAT-box elements, in addition to few other elements found in the upstream promoter region. This might point to a possible role of the intronic region in gene regulation in CamMADS genes [53].

In $A$. thaliana, most type I MADS-box genes are expressed weakly, and their function is not as clear as type II MADS-box genes. The expression of CamMADS17 and CamMADS20 genes in the flower bud tissues suggested that they might have a role in flower development. This is in line with what some studies suggest that type I genes are involved in $A$. thaliana reproduction and development $[32,46]$. It is worth noting that some genes appear to have no expression in any C. americana tissue. This might be due to the fact that some of the MADS-box genes are activated in response to certain environmental cues and abiotic stress responses, such as: temperature, salinity, drought, and wound response [8,9]. Another possibility is that these gens might be pseudogenes being transcribed to RNA at a very low level, with no function, or might be redundant genes going through neofunctionalization process. The presence of two or more orthologs of $A$. thaliana MADS-box genes either reflect a functional redundancy, or some of these genes might have acquired new functions, or they might differ in response to different environmental cues to fine tune gene expression level in C. americana. The C. americana genome analyses have revealed three putative whole-genome duplication events [2]. Gene duplication events were also recently reported in mints [43]. Whole genome duplication events might have contributed to MADS-box gene family expansion.

\section{Conclusions}

Based on the latest $C$. americana genome sequence and RNA-Seq data, 78 CamMADS genes were identified using bioinformatics tools and were classified as M-type ( $\mathrm{M} \alpha$ and $\mathrm{M} \gamma$ ) and MIKC-type (MIKC ${ }^{*}$ and $\mathrm{MIKC}^{\mathrm{C}}$ ) according to their evolutionary relationships 
and protein structure characteristics. The $\mathrm{M} \beta$-type of type I MADS-box genes was absent in C. americana, as it was absent in $S$. indicum and $U$. gibba. The absence of $\mathrm{M} \beta$-type genes in these species, which are all members of the Lamiales order, might hint to a close relationship between Lamiacaea family and Lentibulariaceae family within the Lamiales order. Gene structure analysis revealed that type II genes contained a greater number of exons than did type I genes. The expression pattern of CamMADS genes in eight tissues, and the cis-regulatory element analysis of their promoter regions suggest an overall conservation of some of the abiotic stress responses and the ABCDE model of flower development functions to some extent in C. americana. The absence of certain elements and the change in expression patterns could point to some MADS-box genes being diversified in functions, or simply to a redundancy in function. This study will help guide future molecular proteinprotein interaction analysis studies to confirm the interactions and functions of each of the CamMADS genes presented.

\section{Materials and Methods}

\subsection{Identification and Sequence Analysis of MADS-Box Genes}

The C. americana (beautyberry) genome and proteome were downloaded from NCBI (PRJNA529675). The hidden Markov model (HMM) profiles of the SFR (type I) domain (PF00319) and Myocyte Enhancer Factor-2 (MEF2) type II domain (PF09047) were retrieved from Pfam [54]. MADS-box genes were identified in the C. americana proteome using the hidden Markov model (HMM) profile corresponding to the Pfam MADS-box family PF00319 and PF09047 domains, using HMMER v. 3.0 [25], and redundant sequences were removed manually. A total of 78 MADS-box proteins were obtained as candidate MADS-box genes. The amino acid sequences were then searched, based on the conserved domains, using ScanProsite and the simple modular architecture research tool (SMART) to confirm that all genes contained the MADS-box domain $[26,27]$. The annotations of the type II (MIKC) genes that were missing the K-domain were corrected by the FGENESH suite $[28,29]$, using the CamMADS genomic DNA in reference to the $S$. indicum genes. The online tool ProtParam [55] was employed to analyze theoretical molecular weights and isoelectric points (PI).

\subsection{Assigning the Location of MADS-Box Genes to the C. americana Genome}

The physical positions of MADS-box genes were mapped to the 17 chromosomes of C. americana using the coding DNA sequence files. The TBtool suite [56] was used to visualize the genes on chromosomes. The OrthoFinder algorithm [57] was used to identify possible duplicated genes.

\subsection{Alignment and Phylogenetic Analysis of MADS-Box Genes}

Type I and type II MADS-box proteins of A. thaliana, S. lycopersicum, S. indicum, and A. trichopoda were downloaded from PlantTFDB 5.0 database [30], then C. americana type I and type II MADS-box full length proteins were aligned to them using UGENE MUSCLE [58] with the following settings (Gap Open: -2.9, Gap Extended: 0.0, Hydrophobicity Multiplier: 1.2, Cluster Method: UPGMA). Two unrooted maximum likelihood (ML) trees of C. americana, A. thaliana, S. lycopersicum, and S. indicum type I and type II MADS-box proteins were constructed using the MEGA-X software $[59,60]$ with the following settings (Bootstrap: 1000, Model: Jones-Taylor-Thornton, Uniform rates, Gaps: Use all sites). Another circular and linear phylogenetic tree of all C. americana MADS-box proteins was constructed using the same method.

\subsection{Gene Structure and Conserved Motif Analysis}

Gene structures were constructed using a GFF3 file downloaded from the GIGA database [61], BioProject (PRJNA529675). The structures were displayed using Gene Structure Display Server (GSDS 2.0) [62]. The MEME server [63] was used to predict conserved motifs with the following parameters: number of repetitions $=$ any, maximum 
number of motifs $=20$, optimum motif width set to $\geq 6$ and $\leq 200$, based on our knowledge of MADS-box protein domains.

\subsection{Expression Profiling of MADS-Box Genes and Cis-Acting Regulatory Element Analysis}

The RNA-Seq data were obtained from GIGA database [61] SRA study (SRP192973). These RNA-Seq data contained the transcriptomes of young leaf, mature leaf, stem, petiole, root, close flower, open flower, and whole fruit. Transcript abundance was calculated by normalized transcripts per million (TPM) values, and data were represented as a heatmap, using MS Excel sheets [64]. The cis-acting regulatory element analysis was performed on $2 \mathrm{~kb}$ upstream promoter sequences of CamMADS genes, using PlantCARE server [65], and the number of elements was presented as a heatmap.

Supplementary Materials: The following are available online at https: / www.mdpi.com/article/ 10.3390/plants10091805/s1, Figure S1: Phylogenetic maximum likelihood tree of Type I MADSbox proteins in C. americana, A. thatiana, S. lycopersicum, S. indicum and A. trichopoda. Figure S2. Phylogenetic maximum likelihood tree of Type II MADS-box proteins in C. americana, A. thaliana, $S$. lycopersicum, S. indicum and A. trichopoda.

Author Contributions: Conceptualization, T.A.; methodology, T.A. and A.M.A.-A.; formal analysis, T.A. and A.M.A.-A.; writing-original draft preparation, T.A. All authors have read and agreed to the published version of the manuscript.

Funding: This research received no external funding.

Institutional Review Board Statement: Not applicable.

Informed Consent Statement: Not applicable.

Data Availability Statement: Data is contained within the article or Supplementary Material.

Conflicts of Interest: The authors declare no conflict of interest.

\section{References}

1. Learning from our elders: Folk Remedy Yields Mosquito-Thwarting Compound. Agricultural Research Magazine, 6 February 2006.

2. Cantrell, C.L.; Klun, J.A.; Bryson, C.T.; Kobaisy, M.; Duke, S.O. Isolation and identification of mosquito bite deterrent terpenoids from leaves of American (Callicarpa americana) and Japanese (Callicarpa japonica) beautyberry. J. Agric. Food Chem. 2005, 15, 5948-5953. [CrossRef]

3. Carroll, J.F.; Cantrell, C.L.; Klun, J.A.; Kramer, M. Repellency of two terpenoid compounds isolated from Callicarpa americana (Lamiaceae) against Ixodes scapularis and Amblyomma americanum ticks. Exp. Appl. Acarol. 2007, 41, 215-224. [CrossRef] [PubMed]

4. Hamilton, J.P.; Godden, G.T.; Lanier, E.; Bhat, W.W.; Kinser, T.J.; Vaillancourt, B.; Wang, H.; Wood, J.C.; Jiang, M.; Soltis, P.S.; et al. Generation of a chromosome-scale genome assembly of the insect-repellent terpenoid-producing Lamiaceae species, Callicarpa americana. GigaScience 2020, 9, giaa093. [CrossRef] [PubMed]

5. Becker, A.; Günter, T. The major clades of MADS-box genes and their role in the development and evolution of flowering plants. Mol. Phylogenetics Evol. 2003, 29, 464-489. [CrossRef]

6. Theissen, G.; Becker, A.; Di Rosa, A.; Kanno, A.; Kim, J.T.; Münster, T.; Winter, K.-U.; Saedler, H. A short history of MADS-box genes in plants. Plant Mol. Biol. 2000, 42, 115-149. [CrossRef]

7. Ng, M.; Yanofsky, M.F. Function and evolution of the plant MADS-box gene family. Nat. Rev. Genet. 2001, 2, 186-195. [CrossRef]

8. Castelán-Muñoz, N.; Herrera, J.; Cajero-Sánchez, W.; Arrizubieta, M.; Trejo, C.; Garcia-Ponce, B.; de la Paz Sánchez, M.; ÁlvarezBuylla, E.R.; Garay-Arroyo, A. MADS-box genes are key components of genetic regulatory networks involved in abiotic stress and plastic developmental responses in plants. Front. Plant Sci. 2019, 10, 853. [CrossRef] [PubMed]

9. Wen, C.Y.; Hu, Z.; Hu, J.; Zhu, Z.; Yu, X.; Cui, B.; Chen, G. Tomato (Solanum lycopersicum) MADS-box transcription factor SIMBP8 regulates drought, salt tolerance and stress-related genes. Plant Growth Regul. 2017, 83, 55-68.

10. Schwarz-Sommer, Z.; Sommer, H. Genetic Control of Flower Development by Homeotic Genes in Antirrhinum majus. Science 1990, 250, 931-936. [CrossRef] [PubMed]

11. Coen, E.S.; Meyerowitz, E.M. The war of the whorls: Genetic interactions controlling flower development. Nature 1991, 353, 31-37. [CrossRef] [PubMed]

12. Theissen, G. Development of floral organ identity: Stories from the MADS house. Curr. Opin. Plant Biol. 2001, 4, 75-85. [CrossRef]

13. Honma, T.; Goto, K. Complexes of MADS-box proteins are sufficient to convert leaves into floral organs. Nature 2001, 409, 525-529. [CrossRef]

14. Causier, B.; Schwarz-Sommer, Z.; Davies, B. Floral organ identity: 20 years of ABCs. Semin. Cell Dev. Biol. 2010, 21, 73-79. [CrossRef] 
15. Immink, R.G.H.; Tonaco, I.A.N.; De Folter, S.; Shchennikova, A.; Van Dijk, A.D.J.; Busscher-Lange, J.; Borst, J.W.; Angenent, G.C. SEPALLATA3: The 'glue' for MADS box transcription factor complex formation. Genome Biol. 2009, 10, 1-16. [CrossRef] [PubMed]

16. Alhindi, T.; Zhang, Z.; Ruelens, P.; Coenen, H.; DeGroote, H.; Iraci, N.; Geuten, K. Protein interaction evolution from promiscuity to specificity with reduced flexibility in an increasingly complex network. Sci. Rep. 2017, 7, 1-15.

17. Alvarez-Buylla, E.R.; Pelaz, S.; Liljegren, S.J.; Gold, S.E.; Burgeff, C.; Ditta, G.S.; de Pouplana, L.R.; Martínez-Castilla, L.; Yanofsky, M.F. An ancestral MADS-box gene duplication occurred before the divergence of plants and animals. Proc. Natl. Acad. Sci. USA 2000, 97, 5328-5333. [CrossRef] [PubMed]

18. Kofuji, R.; Sumikawa, N.; Yamasaki, M.; Kondo, K.; Ueda, K.; Ito, M.; Hasebe, M. Evolution and divergence of the MADS-box gene family based on genome-wide expression analyses. Mol. Biol. Evol. 2003, 20, 1963-1977. [CrossRef] [PubMed]

19. Yang, Y.; Laura, F.; Thomas, J. The K domain mediates heterodimerization of the Arabidopsis floral organ identity proteins, APETALA3 and PISTILLATA. Plant J. 2003, 33, 47-59. [CrossRef]

20. Kaufmann, K.; Rainer, M.; Günter, T. MIKC-type MADS-domain proteins: Structural modularity, protein interactions and network evolution in land plants. Gene 2005, 347, 183-198. [CrossRef] [PubMed]

21. Immink, R.G.H.; Kerstin, K.; Gerco, C.A. The 'ABC' of MADS domain protein behaviour and interactions. Acad. Press Semin. Cell Dev. Biol. 2010, 21, 87-93. [CrossRef]

22. Kwantes, M.; Daniela, L.; Wim, V. How MIKC* MADS-box genes originated and evidence for their conserved function throughout the evolution of vascular plant gametophytes. Mol. Biol. Evol. 2012, 29, 293-302. [CrossRef] [PubMed]

23. Gramzow, L.; Guenter, T. A hitchhiker's guide to the MADS world of plants. Genome Biol. 2010, 11, 214. [CrossRef]

24. Jones, W.P.; Kinghorn, A.D. Biologically active natural products of the genus Callicarpa. Curr. Bioactive Compd. 2008, 4, 15-32. [CrossRef] [PubMed]

25. HMMR v3.3.2. Available online: http://hmmer.org/2021 (accessed on 15 June 2021).

26. Letunic, I.; Supriya, K.; Peer, B. SMART: Recent updates, new developments and status in 2020. Nucleic Acids Res. 2021, 49, D458-D460. [CrossRef] [PubMed]

27. Sigrist, C.J.A.; Cerutti, L.; Hulo, N.; Gattiker, A.; Falquet, L.; Pagni, M.; Bairoch, A.; Bucher, P. PROSITE: A documented database using patterns and profiles as motif descriptors. Brief Bioinform. 2002, 3, 265-274. [CrossRef] [PubMed]

28. Solovyev, V.; Kosarev, P.; Seledsov, I.; Vorobyev, D. Automatic annotation of eukaryotic genes, pseudogenes and promoters. Genome Biol. 2006, 7, 1-12. [CrossRef]

29. Tian, F.; Yang, D.-C.; Meng, Y.-Q.; Jin, J.; Gao, G. PlantRegMap: Charting functional regulatory maps in plants. Nucleic Acids Res. 2020, 48, D1104-D1113. [CrossRef]

30. Jin, J.; Tian, F.; Yang, D.-C.; Meng, Y.-Q.; Kong, L.; Luo, J.; Gao, G. PlantTFDB 4.0: Toward a central hub for transcription factors and regulatory interactions in plants. Nucleic Acids Res. 2016, 45, D1040-D1045. [CrossRef] [PubMed]

31. Gramzow, L.; Lisa, W.; Günter, T. MADS goes genomic in conifers: Towards determining the ancestral set of MADS-box genes in seed plants. Ann. Bot. 2017, 114, 1407-1429. [CrossRef]

32. Parenicová, L.; de Folter, S.; Kieffer, M.; Horner, D.S.; Favalli, C.; Busscher, J.; Cook, H.E.; Ingram, R.M.; Kater, M.M.; Davies, B.; et al. Molecular and phylogenetic analyses of the complete MADS-box transcription factor family in Arabidopsis: New openings to the MADS world. Plant Cell 2003, 15, 1538-1551. [CrossRef]

33. Wang, Y.; Zhang, J.; Hu, Z.; Guo, X.; Tian, S.; Chen, G. Genome-Wide analysis of the MADS-Box transcription factor family in Solanum lycopersicum. Int. J. Mol. Sci. 2019, 20, 2961. [CrossRef]

34. Xin, W.; Wang, L.; Yu, J.; Zhang, Y.; Li, D.; Zhang, X. Genome-wide identification and analysis of the MADS-box gene family in sesame. Gene 2015, 569, 66-76.

35. Simonini, S.; Roig-Villanova, I.; Gregis, V.; Colombo, B.; Colombo, L.; Kater, M.M. Basic pentacysteine proteins mediate MADS domain complex binding to the DNA for tissue-specific expression of target genes in Arabidopsis. Plant Cell 2012, 24, 4163-4172. [CrossRef] [PubMed]

36. Mahmoudi, T.; Katsani, K.R.; Verrijzer, C.P. GAGA can mediate enhancer function in trans by linking two separate DNA molecules. EMBO J. 2002, 21, 1775-1781. [CrossRef]

37. Upadhyay, A.K.; Chacko, A.R.; Gandhimathi, A.; Ghosh, P.; Harini, K.; Joseph, A.P.; Joshi, A.G.; Karpe, S.D.; Kaushik, N.; Kuravadi, N.; et al. Genome sequencing of herb Tulsi (Ocimum tenuiflorum) unravels key genes behind its strong medicinal properties. BMC Plant Biol. 2015, 15, 1-20. [CrossRef] [PubMed]

38. Shu, Y.; Yu, D.; Wang, D.; Guo, D.; Guo, C. Genome-wide survey and expression analysis of the MADS-box gene family in soybean. Mol. Biol. Rep. 2013, 40, 3901-3911. [CrossRef]

39. Kagale, S.; Koh, C.; Nixon, J.; Bollina, V.; Clarke, W.E.; Tuteja, R.; Spillane, C.; Robinson, S.J.; Links, M.; Clarke, C.; et al. The emerging biofuel crop Camelina sativa retains a highly undifferentiated hexaploid genome structure. Nat. Commun. 2014, 5, 1-11. [CrossRef] [PubMed]

40. Veron, A.S.; Kaufmann, K.; Bornberg-Bauer, E. Evidence of interaction network evolution by whole-genome duplications: A case study in MADS-Box proteins. Mol. Biol. Evol. 2007, 24, 670-678. [CrossRef]

41. Vekemans, D.; Proost, S.; Vanneste, K.; Coenen, H.; Viaene, T.; Ruelens, P.; Maere, S.; de Peer, Y.V.; Geuten, K. Gamma paleohexaploidy in the stem lineage of core eudicots: Significance for MADS-box gene and species diversification. Mol. Biol. Evol. 2012, 29, 3793-3806. [CrossRef] 
42. Ohno, S. Evolution by Gene Duplication; Springer Science \& Business Media: Berlin, Germany, 2013.

43. Godden, G.T.; Taliesin, J.K.; Pamela, S.S.; Douglas, E.S. Phylotranscriptomic analyses reveal asymmetrical gene duplication dynamics and signatures of ancient polyploidy in mints. Genome Biol. Evol. 2019, 11, 3393-3408. [CrossRef]

44. Lemons, D.; William, M. Genomic evolution of Hox gene clusters. Science 2006, 313, 1918-1922. [CrossRef] [PubMed]

45. Theißen, G.; Rümpler, F.; Gramzow, L.A. Array of MADS-box genes: Facilitator for rapid adaptation? Trends Plant Sci. 2018, 23, 563-576. [CrossRef]

46. Bemer, M.; Heijmans, K.; Airoldi, C.; Davies, B.; Angenent, G.C. An atlas of type I MADS box gene expression during female gametophyte and seed development in Arabidopsis. Plant Physiol. 2010, 154, 287-300. [CrossRef] [PubMed]

47. Coenen, H.; Viaene, T.; Vandenbussche, M.; Geuten, K. TM8 represses developmental timing in Nicotiana benthamiana and has functionally diversified in angiosperms. BMC Plant Biol. 2018, 18, 1-16. [CrossRef]

48. Tani, E.; Polidoros, A.; Flemetakis, E.; Stedel, C.; Kalloniati, C.; Demetriou, K.; Katinakis, P.; Tsaftaris, A.S. Characterization and expression analysis of AGAMOUS-like, SEEDSTICK-like, and SEPALLATA-like MADS-box genes in peach (Prunus persica) fruit. Plant Physiol. Biochem. 2009, 47, 690-700. [CrossRef] [PubMed]

49. Giménez, E.; Dominguez, E.; Pineda, B.; Heredia, A.; Moreno, V.; Lozano, R.; Angosto, T. Transcriptional activity of the MADS box ARLEQUIN/TOMATO AGAMOUS-LIKE1 gene is required for cuticle development of tomato fruit. Plant Physiol. 2015, 168, 1036-1048. [CrossRef]

50. Choudhury, S.R.; Roy, S.; Nag, A.; Singh, S.K.; Sengupta, D.N. Characterization of an AGAMOUS-like MADS box protein, a probable constituent of flowering and fruit ripening regulatory system in banana. PLoS ONE 2012, 7, e44361. [CrossRef]

51. Song, Y.H.; Yoo, C.M.; Hong, A.P.; Kim, S.H.; Jeong, H.J.; Shin, S.Y.; Kim, H.J.; Yun, D.-J.; Lim, C.O.; Bahk, J.D.; et al. DNA-binding study identifies C-box and hybrid C/G-box or C/A-box motifs as high-affinity binding sites for STF1 and LONG HYPOCOTYL5 proteins. Plant Physiol. 2008, 146, 1862-1877. [CrossRef]

52. Petrella, R.; Caselli, F.; Roig-Villanova, I.; Vignati, V.; Chiara, M.; Ezquer, I.; Tadini, L.; Kater, M.M.; Gregis, V. BPC transcription factors and a Polycomb Group protein confine the expression of the ovule identity gene SEEDSTICK in Arabidopsis. Plant J. 2020, 102, 582-599. [CrossRef]

53. Schauer, S.E.; Schlüter, P.M.; Baskar, R.; Gheyselinck, J.; Bolaños, A.; Curtis, M.D.; Grossniklaus, U. Intronic regulatory elements determine the divergent expression patterns of AGAMOUS-LIKE6 subfamily members in Arabidopsis. Plant J. 2009, 59, 987-1000. [CrossRef] [PubMed]

54. Mistry, J.; Chuguransky, S.; Williams, L.; Qureshi, M.; Salazar, G.A.; Sonnhammer, E.L.L.; Tosatto, E.S.C.; Paladin, L.; Raj, S.; Richardson, L.J.; et al. Pfam: The protein families database in 2021. Nucleic Acids Res. 2021, 49, D412-D419. [CrossRef]

55. Gasteiger, E.; Christine, H.; Alexandre, G.; Marc, R.W.; Ron, D.A.; Amos, B. Protein identification and analysis tools on the ExPASy server. In The Proteomics Protocols Handbook; Humana Press: Totowa, NJ, USA, 2005; pp. 571-607.

56. Chen, C.; Chen, H.; Zhang, Y.; Thomas, H.R.; Frank, M.H.; He, Y.; Xia, R. TBtools: An integrative toolkit developed for interactive analyses of big biological data. Mol. Plant 2020, 13, 1194-1202. [CrossRef] [PubMed]

57. Emms, D.M.; Kelly, S. OrthoFinder: Phylogenetic orthology inference for comparative genomics. Genome Biol. 2019, 20, 1-14. [CrossRef] [PubMed]

58. Okonechnikov, K.; Golosova, O.; Fursov, M. Unipro UGENE: A unified bioinformatics toolkit. Bioinformatics 2012, 28 , 1166-1167. [CrossRef] [PubMed]

59. Jones, D.T.; William, R.T.; Janet, M.T. The rapid generation of mutation data matrices from protein sequences. Bioinformatics 1992, 8, 275-282. [CrossRef]

60. Kumar, S.; Stecher, G.; Li, M.; Knyaz, C.; Tamura, K.; Battistuzzi, F.U. MEGA X: Molecular evolutionary genetics analysis across computing platforms. Mol. Biol. Evol. 2018, 35, 1547. [CrossRef]

61. Sneddon, T.P.; Li, P.; Edmunds, S.C. GigaDB: Announcing the GigaScience database. GigaScience 2012, 1, 11. [CrossRef] [PubMed]

62. Hu, B.; Jin, J.; Guo, A.-Y.; Zhang, H.; Luo, J.; Gao, G. GSDS 2.0: An upgraded gene feature visualization server. Bioinformatics 2015, 31, 1296-1297. [CrossRef]

63. Bailey, T.L.; Boden, M.; Buske, F.A.; Frith, M.; Grant, C.E.; Clementi, L.; Ren, J.; Li, W.W.; Noble, W.S. MEME SUITE: Tools for motif discovery and searching. Nucleic Acids Res. 2009, 37, W202-W208. [CrossRef] [PubMed]

64. Microsoft Corporation. Microsoft Excel. 2018. Available online: https:/ / office.microsoft.com/ excel (accessed on 15 June 2021).

65. Magali, L.; Déhais, P.; Thijs, G.; Marchal, K.; Moreau, Y.; de Peer, Y.V.; Rouzé, P.; Rombauts, S. PlantCARE, a database of plant cis-acting regulatory elements and a portal to tools for in silico analysis of promoter sequences. Nucleic Acids Res. 2002, 30, 325-327. 